\title{
Building and Diffusing the Image of Cultural Heritage: Pausanias in Ancient Greece and the Voyages Pittoresques et Romantiques in $19^{\text {th }}$ Century France
}

\author{
By Paul Claval* \\ Colette Jourdain-Annequin
}

This paper offers a comparative study of two examples of building and diffusing the image of cultural heritages: (i) that of Pausanias giving a panorama of what had been the culture of Classical Greece both for the Hellenistic elites of Eastern Mediterranean and for the Roman ones; (ii) that of Charles Nodier and baron Taylor building an image of medieval and Renaissance France for the romantic public of $19^{\text {th }}$ century France. In both cases, the problem was to offer and diffuse an inventory of the past in order to anchor identities of the time. Greek identity in the case of Pausanias and French national one in the case of Charles Nodier and Baron Taylor were in a way similar, but it was interesting to show how much they differed by their political significance and by the means they relied on.

Keywords: Communication, Cultural identity, inheritance, National or ethnic narrative, religious identity.

\section{Pausanias and the Greek Heritage}

Pausanias was a Greek from the Asia Minor who, at the time of the Roman peace, apogee of an Empire, in which Greece was no more than a Province, came back to the land of his ancestors. Tirelessly, he went all over it, discovered its geography, stopped in front of every monument of its past greatness, mentioned the temples encountered on his itinerary (including those that, in his time, were ruined), wondered about statues, images of the gods who inhabited them, described the tombs that contributed to draw the religious space of the city and to make it the memory of the community (JourdainAnnequin 2014).

The enormous documentation he gathered made of the Periegesis an extraordinary guide (Habicht 1985/1998, Elsner 1992) for whom would follow in his visit to the author who was sometimes named the "Greek Baedeker". Pausanias was, however, much more than a guide (and an inescapable source for archaeologists and a historian!) (Bingen 1996, Ellinger 2005, Noeppler and Piérart 2001, Pirenne-Delforge and Purnelle 1997): drawing in this way from the sources of his own culture, it was the identity of the people that he wished to pass on, all the more since he knew that it was likely, thanks to the weight of

\footnotetext{
* Emeritus Professor, Université de Paris-Sorbonne, France.

*Emeritus Professor, Université de Grenoble, France.
} 
this prestigious past, to affirm in front of Rome, then dominant, what was and what remained the greatness of Greece (Jost 2006).

\section{Pausanias and the Periegesis}

We have few testimonies on the author, who is mainly known through the information he gave himself in his work ${ }^{1}$. He was a Greek from Asia Minor, certainly born in the region of Magnesia of Mount Sipylus, often quoted in his text with this precision: "at home".

The time was that of Roman peace, the apogee of an Empire in which Greece was only a province. People know that the writing of the Description of Greece started at about 150 A. D. - Pausanias was then 35 years old. The ten books that it contains were completed thirty years later. It was thus a work of the second half of the Second Century A. D., contemporaneous with what was called the "second sophistry" or also the "Greek Renaissance", a work inscribed in a very precise moment of history: that was when historical Greece, as tiny as it was on the political map, was becoming, for the Imperial aristocracy, a prestigious land, loaded with memories, but still imperfectly known.

Pausanias was first a great traveller - a feature shared by the tourists and the pilgrims. Before starting his Description of Greece, he had visited Egypt (and even Upper Egypt); he knew Syria and Palestine, Libya equally. He had travelled up and down these provinces somewhat exterior to Greece that were Macedon and Epirus. He knew quite evidently Rome and Italy... We don't know if he had kept a diary during all these travels; in any case, only his notes on continental Greece - the Roman Province of Achaia, as people said - were conserved and published.

The publication of the ten books of Periegesis opened with the description of Athens and Attica, "the Greece of Greece" as said by the epitaph of Euripides, and it was certainly not by chance (Book 1). It next went on, in an order, which may appear logical to a geographer, to Isthmus, Corinth and Argolis (Book 2). His description of Peloponnesus followed first the coastal areas: at Hermes, he started his Book 3, which dealt with Laconia; he then described the other great plain of Peloponnesus: Messenia (Book 4). He so followed the coast and went on northwards to visit the land of Elis. The description of Olympia, evidently very long, explained that two books were needed for relating his visit to the region (Book 5 and 6). Crossing the Larissa, he left the land of Elis, reached Achaia and, from Patras, its most important city, he moved along the Northern shore of the Peloponnesus (Book 7) before reaching the heart of the Peninsula, the central and mountainous region of Arcadia (Book 8).

\footnotetext{
${ }^{1}$ The author of the Periegesis was taken for other Pausanias: for a sophist from Damask who would have written on Syria and Phoenicia, and overall for the Pausanias mentioned by Philostratus in the Life of Sophists. This latter, still held in the 19th Century for the author of the Description of Greece, came from Cappadocia, which, for as well historical as literary reasons, could decidedly not be.
} 
Map 1. Pausanias' Travels in Greece

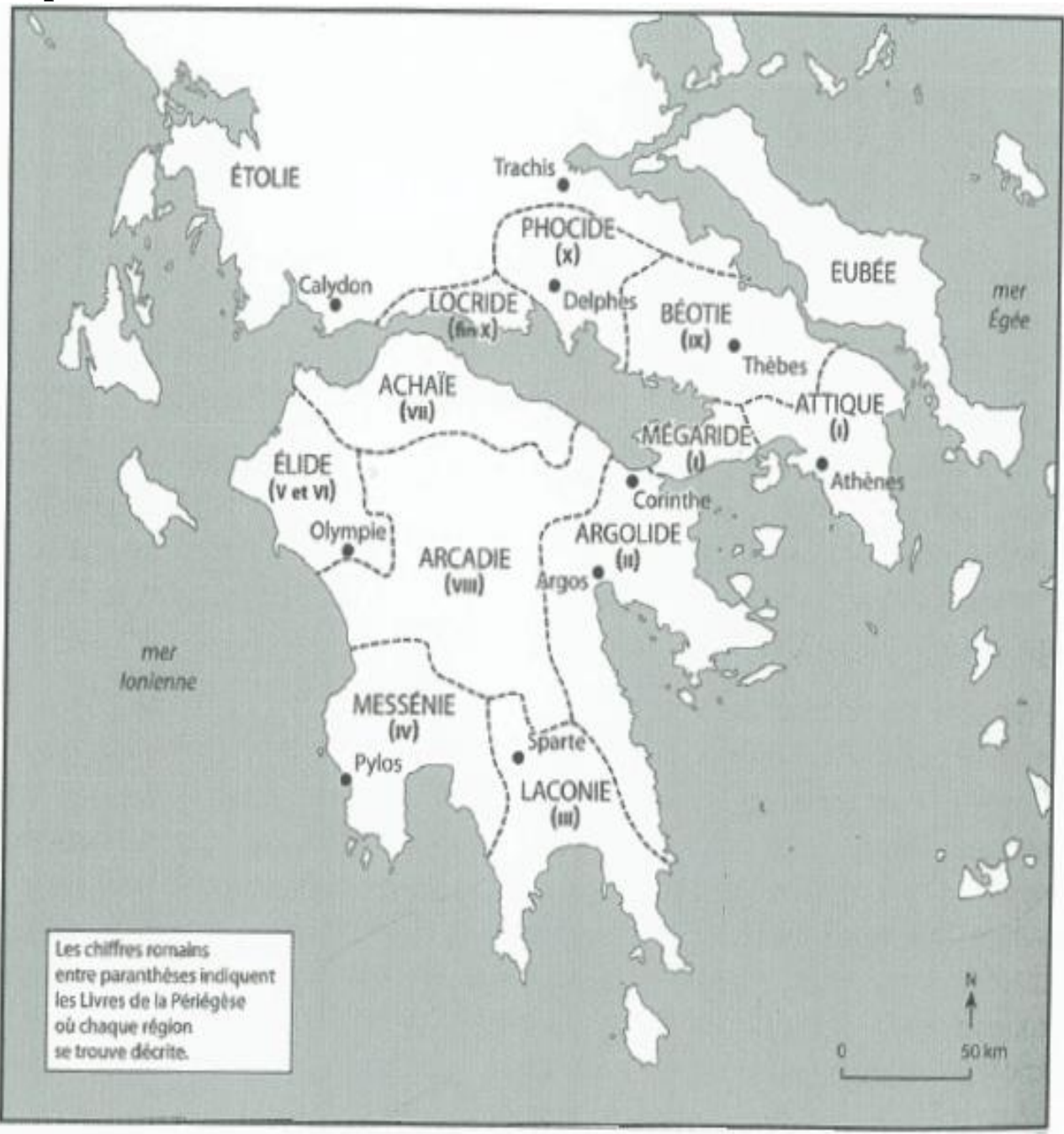

Source: Jourdain Annequin 2014: 238.

After this immersion in what could be called deep Greece, Pausanias went back to the boundaries of Attica; his description of Beotia (Book 9) started with Plataea, then Thebes. He entered then in Phocis, where his main objective was obviously the visit to the sanctuary of Delphi, another great attractive place for pilgrims (not only Greek, otherwise). This description of Phocis and of the neighbouring Locris closed the Periegesis. It was the tenth and ultimate Book.

The book was systematically organized, as we see it, and the description was first an itinerary. In order to keep a short presentation, I choose only two very different examples of the organization of these itineraries. In order to do it, I use the maps prepared for the Greek edition of Papachetzes (the most important names have been, however, anglicized). 
Map 2. Pausanias' Itinerary in Messenia

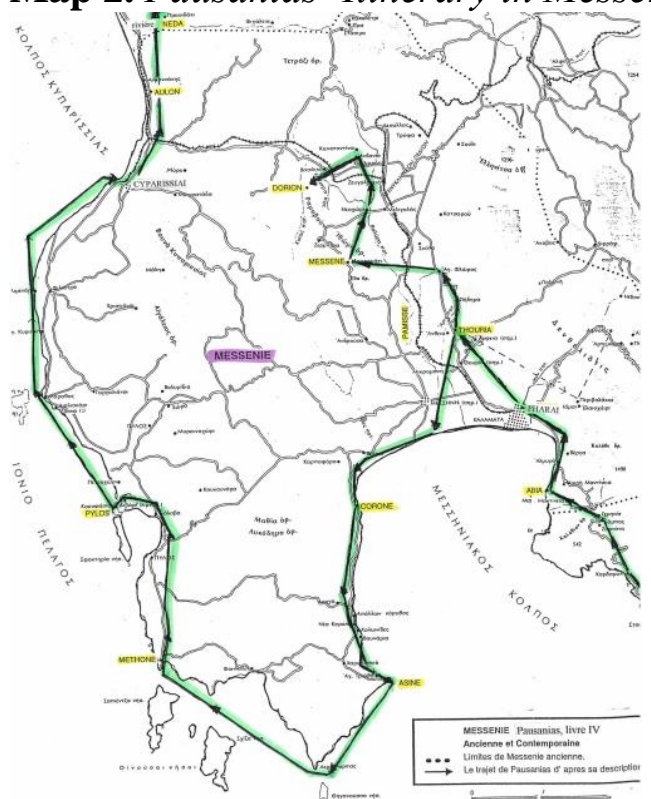

Source: Papachetzes (1974), Messenia, book IV.

In Messenia (Book 4), the itinerary was essentially a coastal, even partly maritime, one. The Periegetes came from Laconia along the gulf of Messenia and "moved up", then, towards Elis, touching the main cities of the region, such as Pylus, the city of the old Nestor in the Homeric narrative of the war of Troy. He moved inland for visiting Messene, the eponym city and, at his time, the centre of the social and artistic life of the region. He moved on, as it may be seen, until Dorium, still an ancient city essentially known through Homeric poets.

Map 3. Pausanias' Itinerary in Argolis

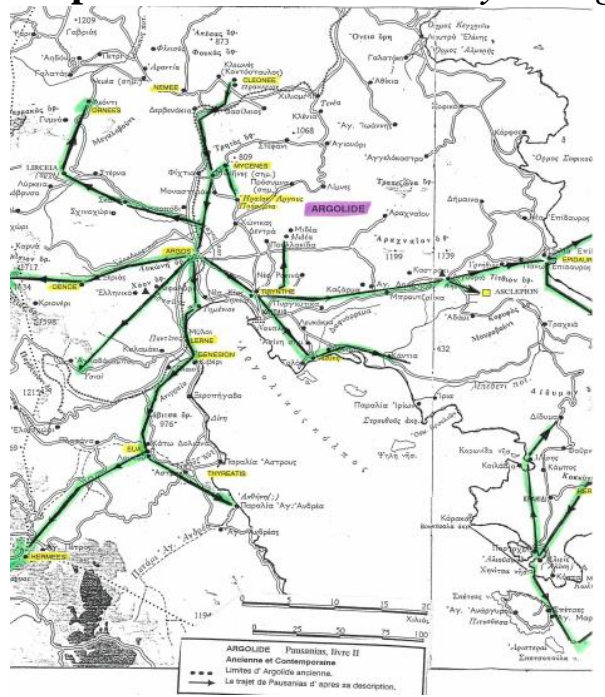

Source: Papachetzes (1974), Pausaniou Hellados Periegis, Argolis, book II. 
The description of Argolis offered a very different pattern. The map covers only a part of Book 2. It was through Cleona that Pausanias entered Argolis, and it was from Argos that he proposed a much more exhaustive tour of the territory. It was worthy to note his passage on the site of old citadels of Mycenae and Tiryns, his detour through the heraion of Argos, one of the most important sanctuaries of archaism. The journey here presented was incomplete: Eastwards, after Epidaurus - from where he made a detour for visiting the famous sanctuary of Asclepius - he moved to the Aegina Island and cities with a prestigious past as Trezen and Hermione, and from then in two other islands of the Saronic Gulf: Hydra and Poros.

People have not to rely on Pausanias to explain his plan. He dove into the description of Attica without a word of introduction and the Periegesis ended as abruptly with the description of Ozolian Locris (he did not describe Opontian Locris).

Once again it is through the story itself that information has to be picked up. Describing the Acropolis, he stopped: " but my narrative must not loiter, as my task is a general description of all Greece (panta to hellenika, all the things of Greece) (I, 26, 4). He was a little more precise when he completed his visit to Athens: "Such are, according to me, the most famous traditions and curiosities of Athens; among the bulk of materials, I tried, from the start, to choose those which are worthy to be noted", "what is worth to be visited", "what is worth of attention", "what has to be memorized", expressions which came back repeatedly in an haunting way throughout his text.

\section{The Project}

What were thus his choices, his criteria of selection?

\section{$\underline{\text { Pausanias and the Natural Curiosities of Greece }}$}

Greek people discovered nature late. It was only in the Hellenistic times, with Theocritus, for instance, that pastoral poetry, rural love and the description of landscapes developed. Nothing equivalent, however, in Pausanias, whose works gave little room to the natural beauties of Greece (Jacquemin 1996).

An example: everyone knows the splendour of the site of Delphi, the impressing character of Phedriades, these "bright rocks" that overlook it. Pausanias only mentioned the rocks of Parnassus in an historic story, when explaining that they began to fall on the Galatians (Gauls) who tried to take and plunder Apollo's Sanctuary. And all along his works, one cannot fail to be amazed by such and indifference, such insensitivity to the beauty of things.

Curiously, the only passage that looked like the description of a landscape was the glance he had on a painting of Polygnotes exposed in the lesche of Cnidians, always in Delphi: 
"People see there a body of water, which looks like that of a river. It is obvious that it is Acheron; it is full of reeds, with fishes looking like shadows more than real fishes. On this river, a boat and a boatman..." (X, $28,1-2)$.

Obviously, this boatman was Charon, transporting the souls to the Hell and this description was that of an imaginary landscape (the descent of Ulysses to Hell).

When travelling, however, Pausanias did not fail to see also the natural beauties of the country: caves, such as that of the Nymph Corytia who, close to Delphi, was "certainly the most beautiful he ever visited"; lakes, some of them very deep as that of Laryma in Beotia and others, full of fish, as lake Copais (also in Beotia) "known for its eels with a prodigious size and a delicious taste" (IX, 24, 1). Others, too, apparently quiet but in fact very dangerous, like that of Alcyones, through which Dionysus moved down to Hell in order to bring back his mother Sémélé: it held back almost every time in its bottom the unwise person who dared to immerse in it (II, 37, 5).

He described also rivers, which sometimes, as the Alphaeus one, disappeared and reappeared farther, rivers able to heal scabies anyone who swimmed across it $(\mathrm{V}, 5,11)$ and others that allowed to forget a lost love: "it is true, this water is more precious, said Pausanias, that the greatest riches" (VII, $23,3)$.

He mainly described springs, many springs, legendary springs such that was born from a kick of the horse Pegasus (II, 31, 9), or that of Lerne, shadowed by the plane tree under which stood the Lernean Hydra killed by Heracles (II, 37, 4). Close to this place, he had seen the Canathos spring, in which, every year, people came to bath the statue of Hera in order to give her back her virginity (II, 38, 2). He has also seen springs with black or white water, springs close to which "people shivered with cold" and others, which gave out "as much heat as the most scorching medicine", springs with water as salted as that of the sea and others more pleasant to drink than milk...

There were as many items in this collection of extraordinary things - and thus "worthy to memorize" - that might be seen in Greece and described for contemporaries thirsty after knowledge.

Pausanias was sensitive to the importance of water in the life of the city (Jourdain-Annequin 2017), but he was even more interested in its powers, either oracular or medical, in its purifying virtues and, as may be understood, in its relations to sacredness. He spoke of the offerings that springs received (flour, honey and cakes, but also the hairs of adolescents just leaving childhood... and even of bridled horses, Pausanias, Periegesis, I, 18, 7; III, 23, $8 ; \mathrm{X}, 8,10$; VII, 7, 1-2). He evoked these statues, which were bathed because, in their water, the divinity found again its vital force (II, 38, 2), or these sacrifices that were practiced, at the spring Hagno for instance, in order to have rain falling over Arcadia (VIII, 38, 4)! And nothing would be told, here, about the waters of Styx that dripped from the rocks of Nonakris and brought death to man as well as to everything that was living on Earth (VIII, 17, 6 and 18, 1-6). 
All these springs, these rivers, theses lakes, these caves and these forests drew, at the end, not a landscape, but a sum of images, knowledge and practices, dreams of beliefs that, sometimes conventional, sometimes more surprising, composed a shimmering painting and allow for an anthropological approach of the realities and of the imagination of past Greeks.

\section{$\underline{\text { Pausanias and Inheritance }}$}

In order not to make my presentation too heavy, I shall stick to the example of Attica (Book 1). His description fitted in with the logic of the itinerary, such as the maps allow relating it: he reached the peninsula through the Sumium, the most conspicuous headland when crossing the Aegean Sea, coming from the Asia Minor. Pausanias pointed out the silver mines of Laurium, then the two ports of Athens: the older, the open harbour of Phalerum "where the sea is closest to the city" and the new port of Peiraeus, the creation of which, he stressed, was in accordance with the naval policy that, at the end of the Medic wars, Themistocles wished for the city.

It was through the Ceramicus neighbourhood and the gate of the Dipylum - the main gate of Athens - that he entered the city, and always very logically, he was soon on the Agora, the centre of the economic and political life of democratic Athens, while the Acropolis, the heart of the archaic royal city, remained, still at his time, the centre of religious life.

The explanations of the Periegetis allowed an intelligent visit to the places: I referred, earlier, to the respective chronology of the two ports of Athens; people learn also that the Ceramicus, the neighbourhood of potters, owed its name from the hero Ceramos, son of Dionysus and Ariadne; on the agora, the function of the main buildings visited by Pausanias was clearly explained: the Bouleuterion, seat of the Council of the Five Hundred; the Tholos, where the prytanees offered sacrifices in the name of the city and welcomed its illustrious guests.

The description of the monument to the eponym heroes offered an opportunity not only to know those heroes who gave their names to the ten tribes of the classical city, but also to deal, through this bias, with the problem of the Clisthenian reform (which founded democracy), for which he referred to Herodotus. But the historian learnt also that Hellenistic sovereigns had added two tribes, to which they had given their own names (Attalus and Ptolemy) and that "in his time", the Emperor Hadrian, philhellene and "concerned about the well-being of his subjects", had done the same thing. Sometimes, regarding a portrait, for instance, there were very long digressions: that of Calypsos allowed him for evoking the invasion of the Galatians (in 279 B. C.) and writing a very long development on this people, which was formerly called Keltoi, he said, and who, "from the extremities of Europe, along an immense sea that cannot be crossed ", dared to march on the sanctuary of Delphi... vain offensive on which he would come back at length, at the end of his journey, when visiting Phocis. Some of these Galatians, he said, settled in the Asia Minor where they were still living at his time. 
It is unnecessary to tell all what the Periegesis taught and still teaches to archaeologists and historians of Greece. Pausanias did not content himself with describing, he quoted, in order to better explain, less accessible sources than those that, in his time, every learnt man was supposed to know: local chronicles, oral testimonies, oracles, inscriptions or epigrams that he could see, still preserved at the time of his visit.

The fact remains that the choices of Pausanias were revealing. These monuments, these objects "the more worthy of memory", were very often the most ancient, the testimonies of the far-off past of Greece (a concern which his itineraries already revealed).

His descriptions themselves were oriented: reaching Piraeus, people would expect that he described the oriental port, cosmopolitan and replete with commercial ships as it has been in the 5th Century B.C., and still was, but no: it was the presence of Themistocles that he evoked, his maritime policy, in short, a great moment of Athenian history.

And this travel in Greece of the $2^{\text {nd }}$ Century A. D., the Century of Pausanias, was mainly a travel through the past. The Periegetes had many other surprises in store for us: whoever wished to visit the Parthenon with his "Pausanias" under his arm would be somewhat disappointed: the description of pediments, as that of the religious statue of Athena, was just an enumeration of the sculpted themes and showed very small concern for aesthetics. People expect more admiration in front of what is considered as the masterpiece of Greek architecture and are amazed, for instance, to observe that in his text (I, XXIV, 8), the story of an invasion of grasshoppers was longer than the description of the statues of Phidias!

Quite evidently for him monuments were essentially the remnants, the spatial traces of the most ancient traditions of Greek culture: it was a very selective image that Pausanias gave of Greece, an archaistic image, for sure...., but one has to insist on a narrative logic which followed a double route :

- a spatial route, which was that of the itinerary,

- a historical and very often even genealogical one, which inscribed the story in a time which was not that of enunciation (the time of Pausanias), but that a far-off past of Greece.

Monuments were a pretext: they served to explain the achievements of great men and more generally, the history of Greece. From the statue of Epaminondas that Pausanias discovered in Thebes (IX, 15, 6), he retained essentially the epigram "in the past, all Greece won independence and freedom."

But monuments served also, they mainly served, to evoke heroes and gods, they told legends, justified cults since it was there that lied the soul of Greece. 


\section{$\underline{\text { Pausanias and the Cultural Inheritance of Greece }}$}

Map 4. Pausanias on the Agora of Athens

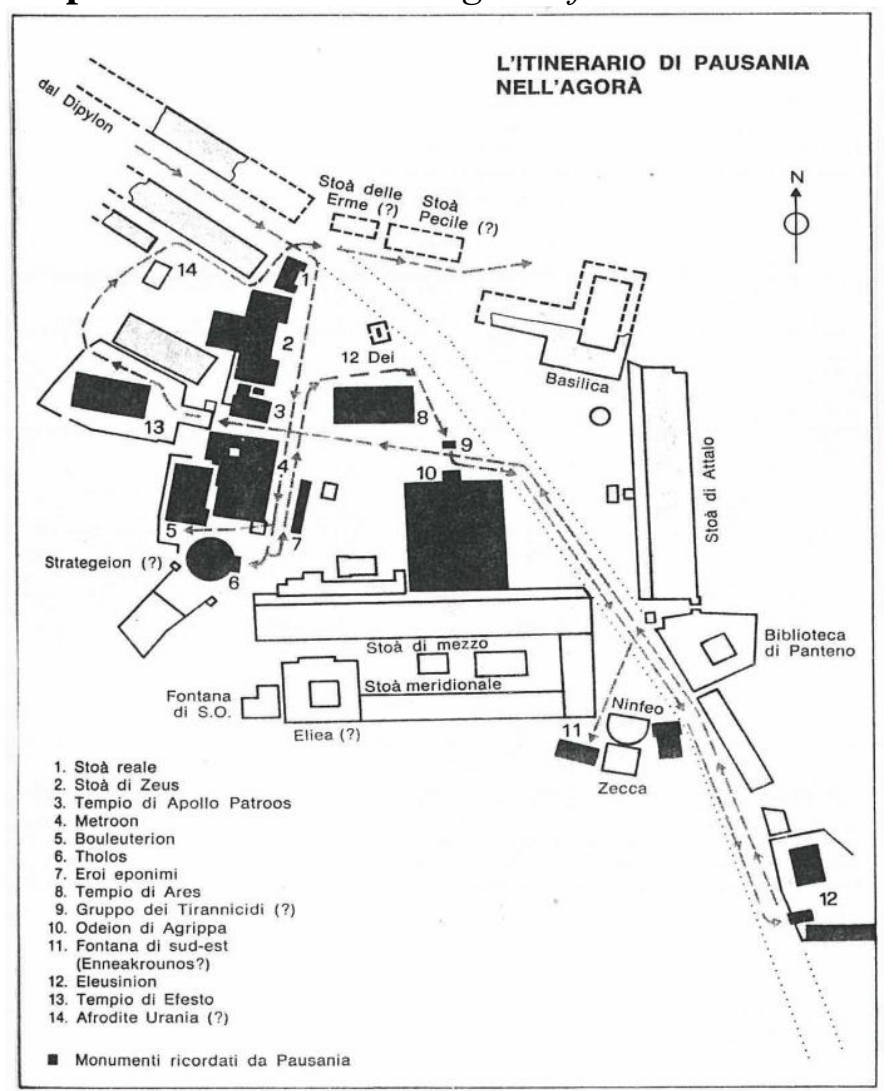

Source: Musti (1987) Pausanias. Guida della Grecia, t.I, l'itinerario di Pausania nell' agora.

On the Agora of Athens, this political and economic place, one can see that Pausanias visited mostly temples: the portico of Zeus, temple of Apollo Patroos, of the Mother of Gods, of Ares, but also Hephaesteion, Eleusinion.

What we note on the agora of Athens, we observe it again and again all along his journey: the places of memory frequented by Pausanias were essentially temples - temples and tombs we have to add immediately, for the latter had obviously the same vocation to depict the religious space in which heroes evolved and gods venerated in the city, heroes and gods whose legend built the memory of the community (Jourdain-Annequin, 1998)..

More than three hundred tombs were in this way described in the ten books of Periegesis. They often marked and gave a rhythm to the territory of the city and sometimes guarded his boundaries: at Sparta, for taking only one example, the tombs of the Hippocontides wove around Heracles, who had defeated them, all a set of relations which united him, in the myth as well as in the cult, with the deities of the Spartan Pantheon. They inscribed him into the history of the city since the victory of the hero had allowed to put back Tyndareus on the throne of Sparta and to insure the continuity of the State. In this way, in this system which founded - or legitimated - the Lacedaemonian civic order, the heroic epic poems reprocessing the old history of Hippocoon 
and his rivalry with his brother Tyndareus, may be read in the tombs scattered over the territory, were articulated with the local cults and drew a space where the political and the religious were tightly interwoven. The past became the guarantee of the unity of the city.

Tombs, thus, and temples in even greater number... In the text of Pausanias, lemmatized in the Centre d' Etude de la Religion Grecque (CIERGA), it is clear that after the words-tools, those which serve to build the narrative, after polis (the city, the main reality of Greece), it was the term hieron (sanctuary) which presented the highest number of occurrences (766 for polis, 675 for hieron) and the names of gods came far ahead those of historic characters ${ }^{2}$.

Pausanias mentioned and described almost every temple found on his route, including those, which, at his time, were in ruins. He pointed out the older, located them sometimes in time - and the historian of religions knows well all what he owes to the untiring and inevitable traveller.

In this way, it was from the sources to his own culture that Pausanias drew, looking for a Greek identity which, for him, lied essentially in its cults: he knew how deeply this identity was rooted into the memory of places. And it was in no way astonishing: as early as the 5th century B. C., at the end of the Medic wars, Herodotus defined the quality of Greeks through the fact that they shared the same religious buildings, accomplished the same acts in their sacrifices to the gods ... gods who, in spite of the particular shape of local pantheons, bore the same name.

And, at the same time, among the objects the most "worthy of memory" which held the attention of the Periegetes, statues could not be forgotten: those of the main deity of the temples he visited, as well as those which represented the gods who surrounded Him (or Her) in His (or Her) sanctuary, or those which were simple offerings.

It was overall the religious statue, the more sacred form of this representation, which interested Pausanias: to represent gods was to show the invisible (an antithesis of fundamental meaning in Greek thought). The statue, had, indeed, one face turned towards the invisible, since it was the god, and a face turned towards the men, since its aim was to make him (or her) visible. For Pausanias, more precisely, the role of the statue seemed really to localize, to fasten on a material - and tangible - object a divine effectiveness, indefinable and invisible in its essence. The statue was thus one of the forms that the forces of the beyond could take on. Of this appropriateness, a confirmation may be found, moreover, in the Oneirocriticon of Artemidores: "No difference may be read [it was, quite evidently, a question of interpretation of dreams] between seeing the goddess [Artemis in this case] as we imagine her and looking at her statue: that they stood with their body of flesh or that they were seen as statues made of matter, that counts for the same" (II, 35)... It was an interesting parallel, moreover, between the representation of the god in space through the image, and his outline of identity such as Greeks could

\footnotetext{
${ }^{2}$ In decreasing order: 358 for Zeus, 357 for Apollo, 311 for Heracles...
} 
apprehend it, after Homer and Hesiod at least, since, if according to Xenophanes or Herodotus, it was through them that, from the start, they had received all their knowledge.

When reading Pausanias, nothing is more interesting than the offered juxtaposition, in so many sanctuaries, of a double image of the deity, a double image of piety.

That of the ancient piety around the old idols of the past, either born from the sea as this image of Dionysus that, one day, the fishermen of Lesbos brought back in their nets; or fallen from the sky as the old wooden statue of Athena, the most sacred of all the images of the poliad deity in Athens; or entrusted by a god to a mortal, as the Palladium (the statue in arms of Athena). The old idols built together with the myths, which explained their rootedness in the city and their relation to the founder, a passably coherent narrative (Jourdain-Annequin 1998).. They were always rallied with a great veneration and generally concealed to the eyes of all, but left sometimes the temple, move through the territory they sanctified, marking the space of the city by their divine presence, marking also its time, according to the rhythm of their outings or their feasts: in this way, in Samos, every year, the discovery of the old idol of Hera was mimed, close to the Imbrasos river and the bush which had seen the goddess to be born. In this way, at Nauplia for Hera, at Phalaris for Athena, took place the ceremony of the bath of the goddess who every year, people said, regained her virginity. One understands that these statues contained a power, a primitive force that it was important to periodically rejuvenate and renew in order for them to assume for the best this protective power, the magical aspect of which was, at the time of Pausanias, still highly felt, and one imagine the pilgrimages and the fervour that such meetings could arouse.

But, to the sides of these idols of the past, symbols of the ancient piety, Pausanias described also - without lingering as much on them - the new images the enriched and self-confident city offered its deities (JourdainAnnequin, 1998). More imposing, more conforming often to the anthropomorphism of religion, they were richer, either made of marble, bronze, or combining ivory and gold. Of this "duality", Pausanias gave many examples. I shall cite only one, that of the temple of Hera in Argos where he could see, close to the ancient effigy in pear tree wood pulled out of the temple of Tiryns, the chriselephanthine statue that, during the 5th Century B. C., Policletes had realized for the mistress of the sanctuary. The attributes of the goddess (the sceptre, the pomegranate) made from now on her functions explicit. Beyond their conspicuous style and the tribute they offered to the city as much as to the deity, the new images did not only show, they told the divine. To the need of adoring was substituted the wish to know a deity, whose efficiency and power had been perhaps attenuated and who, in his or her temple - open to everyone had only as a function to be seen.

The travel of Pausanias, without any doubt, turned into a pilgrimage (Elsner 1992): "It is mainly to see this Demeter that I came to Phigalia" (VIII, 42, 11), did he admit when visiting Arcadia and the relation was constant between the places he visited and the histories, the myths that they evoked. 
Moreover he displayed a remarkable interest in the rituals and an acute sense of sacredness. What proves it was the meticulous description that he gave, at Olympia, of the monthly ritual performed by the priests on every one of the altars of the sanctuary; what proves it also, quite evidently, was the care with which he tried to report the diversity of the homage paid to the deity, from the vegetal offering to the thusia, the bloody sacrifice, constitutive act of the cult in Greece. His interest, even more acute, for some as ancient as strange customs, proved it also: the incredible sacrifice that, in Hermione for instance, was offered to Demeter during the feasts called Chthonia "in order that the territory throve and grew". The feast, each year, gathered a long procession of priests, magistrates in office, men and women of the city, followed by children dressed in white. The victim, the most beautiful cow of the herd, was pushed towards the temple, and the gates were closed on it, and four old ladies which were waiting for it inside, in charge, as said Pausanias, "to dispatch the cow" (II, 35, 5 à 8), that was, here, to slit the throat of the victim ${ }^{3} \ldots$ and since they were four victims, this scenario was repeated four times... That the women were in charge to kill was already exceptional, that this killing would take place secretly was even more and, on this point, Pausanias insisted: he really had seen nothing similar, neither he nor anyone else.

Other strange procession, over which Pausanias lingered: that of Daidala of Plataea, in Boeotia, which celebrated, the myth said, the reconciliation of Hera and Zeus, her too inconstant spouse. The rituals bore the mark of the most remote antiquity; as we may understand, they puzzled Pausanias. They were crows, which designated to Plateans that of the trees which would serve to prepare the daidala, the simply veiled wooden images, which played an essential role in the ritual. The fourteen rivals of Hera, so represented, were perched on so many chariots, each one flanked by a young woman in flesh and bone who played the role - usually in the wedding ceremonies - of the driver of the fiancée. In the myth, the anger of Hera fell when, unveiling the pseudofiancée, she discovered that it was a lure: in the ritual, the fourteen statues were finally burnt on the altar, an altar made of squared-off logs, which also flared up.

But far from these "curiosities", it still should be necessary to speak about these pilgrimages, which were a capital aspect of the religious culture of pagan Antiquity. The sanctuaries attracted, indeed, important groups who came for participating or simply assisting in the great games of Greece, consulting the oracle, venerating the idols or "relics" (the great sanctuaries have very often their tomb), or also sleeping in the sanctuaries of Asclepius in order to see, when dreaming, the physician god and obtain health from him.

But we cannot stop there: we have to evoke the attitude of Pausanias in front of other forms of cult, some mysteries which required another involvement: discovering the new statue of Hera in Argos, the Periegetis refused to relate what people said of the pomegranate she held in one hand "since it was a mystery", and we discovered very soon that this tourist, visiting

\footnotetext{
${ }^{3}$ The tool chosen for cutting the throat is not the makhaira flanked by the axe (pelekus), but the sickle, a tool here diverted from is agricultural function.
} 
the sacred sites of Greece, was no more a simple observer, but a pilgrim. In some sanctuaries, he forgot his role of being a guide: he left the reader beyond the sacred walls since they were things that the layman had not to see, words that he had not to hear. We even read the tale of a dream which informed the Periegetis about what he could, or could not, reveal (IV, 33, 4-5). The taboo of what was ineffable and inexpressible was not contravened ${ }^{4}$.

Better, as his contemporary of Latin language Apuleius, he was a potential initiate of the sanctuaries he visited. He was, we know, initiated to the mysteries of Eleusis.

The anthropological interest of the Periegesis lies in this link that Pausanias established between the exterior sign of sacredness: tombs, temples, statues, and the experience itself of sacredness (Pirenne-Delforge 2008).

Of course, he may appear, centuries after, as the model of these tourists who, inheritors of the humanistic ideal and thirsty of classical culture, travelled through Italy and Greece in search of ancient ruins. Just like the Chateaubriand of the Itinéraires about whom Tzvetan Todorov ${ }^{5}$ is ironical, who sees only in Egypt the cradle of sciences and the mother of religions and in Jerusalem not an alive city, but the place of an historic narrative, every visited site evoked for the Periegetis memories of the past. The indifference, with which he visited Corinth, destroyed by Mummius and repopulated by a Roman colony, was certainly the best proof of that!

Fundamental difference, however: when Chateaubriand was a tourist abroad, Pausanias came to draw from the sources of his own culture, looking for a cultural Greek identity liable to confront, thanks to the weight of a prestigious past, the realities of the Second Century A. D. which have made of Greece a simple province of the Roman Empire. And even if Scylla, "who gravely offended the cities and gods of Greece" (I, 20, 7) was no more in office, even if the time was that of Hadrian the philhellene and of Antonine "the most religious of all the men" (VIII, 43, 1-5), the centre of power was elsewhere and Rome was this "other" in relation to which it was important to define Greece. Speaking about Greece - in the singular - was mainly speaking about its culture: because it was that which made its identity: about its language, obviously, and about its poets who very early had, with the War of Troy, sung the then shared history of Greece.

Christian Jacob (1980: 35-67) had already showed up to what point the landscapes of the Periegesis were haunted, up to what point the itinerary of Pausanias was superimposed on that of gods and heroes, up to what point these places he described were for him loaded with "an ancient history and a rich memory" (Jacob 1980).

The Greek identity - it becomes truer and truer as he went on in his travel - , the Periegetis found it in the deep sense of sacredness, in those sanctuaries, those images of cult, those rituals that he described meticulously, but also in

\footnotetext{
${ }^{4}$ A feeling which comes back several times : VIII, 5,5 et 10, 3 ; VIII, 38, 6 ; IX, 25, 9-10; X, 30,$5 ; \mathrm{X}, 32,17 \ldots$ It is worthy to remark that this attitude does appear progressively and express itself only in the last books.

${ }^{5}$ Nous et les autres, Paris, 1992, p. 404-406
} 
those mythic stories that each of these places, each of this monuments, each of these objects evoked ... essential mythical stories since it was in them that the identity of Greece lied, since they gave it its meaning.

\section{Conclusion}

The Greece of Pausanias was no more the Greece of cities and reading the Periegesis attracts, too, one's attention on what has definitely disappeared. Corinth has been plundered, its temples had been ruined, as those of Nemeus or Elis, deprived of their statues of cult. Divine effigies have been burnt, other, on the contrary remained unfinished as those that Theocomos had, with the help of Phidias, realized the temple of Olympian Zeus in Megara, and Pausanias could still see, at the back of the naos, some of the wooden pieces that had to been covered with ivory or gold (I, 40, 4).

This Grand Tour in the Greece of the second century A.D. is, in fact, a travel in the past, and it is a very selective and archaistic image of the land of his ancestors that he pass over to his contemporaries and posterity: still enchanted, nature resounds of the footsteps of the heroes who travel it up and down, waters are peopled of nymphs, caves and woods are consecrated to gods. The towns and the monuments that adorn them talk at the same time about the power of cities and the strength of a cultural identity, which is that of the Greek people.

Neither Blue Guide nor Baedeker, the Periegesis, story of the long journeys of Pausanias, is really a search for knowledge, an immersion into sacredness and a past able to claim, in front of Rome, centre of the power, the greatness of Greece.

\section{Baron Taylor, Charles Nodier, Alphonse De Cailleux and French Monumental Heritage}

\section{The Context}

After the French Revolution, a deep transformation occurred in the French sensibility. The new democratic ideals permeated the whole society, which explained that history became increasingly a national one and stressed the way it gave its identity to the people. At the same time, a reaction against many aspects of the revolutionary era appeared. It was expressed through a new curiosity for the time when the nation was built, mainly the Middle Ages and Renaissance and, thanks to Chateaubriand, for the Roman Catholic past of France. After the cult for the Supreme Being of the Revolution, it stressed the signification of the traditional religion of the majority of the French people.

In its first period, French romanticism developed in this way a strong interest for the national cultural heritage. At the beginning of the $19^{\text {th }}$ century and until the Revolution of 1830, it was a somewhat contradictory movement: it had inherited from the Revolution - and through Mme de Stael, from Herder 
and the German romanticism - its interest in the French people, but at the same time, it considered Monarchy as the political regime that suited best France. In a word, it harboured a mixture of revolutionary and reactionary themes.

As a consequence, it contributed to the development of new forms of intellectual curiosity in French history: attention was drawn to the national history and its medieval and Renaissance forms. The Revolution had destroyed or impaired a part of French heritage in the field of architecture and sculpture: many churches or castle have been used as quarries by the neighbouring villages or towns - the magnificent abbey of Cluny for instance, the greatest church in Christianity after Saint Peter in Rome, had been razed to the ground in a few years.

\section{The Authors}

A new generation of writers, historians and archaeologists contributed to the development of a new interpretation of French culture and history. They chose as models Shakespeare rather than Racine, Walter Scott rather than Diderot or Rousseau. Charles Nodier (1780-1844) was one of the senior members of this group. He was born and raised in Franche-Comté, a part of Eastern France with a conservative tradition. He had a strong taste for popular literature as exemplified in old legends. He was interested in fantastic stories. He settled permanently in Paris at the time of the Restoration of the Bourbons' monarchy.

Nodier soon appeared as a leader of the Romantic Movement. He received weekly a group of young romantic artists and writers in his apartment located in de Choiseul Street. Two young men trained as a designer and a painter for the first in Paris, Isidore Taylor (1789-1876), and architecture for the second, Alphonse de Cailleux (1788-1876), entered this group and became friends of Charles Nodier en 1818.

Born in Brussels from an English father and a Flemish mother with an old British ancestry, Taylor had been raised in France since his parents had to leave Belgium because of the first consequences of the French Revolution in this country (Plazuola 1989). He was fond of theatre and had an inclination for literature. He learnt drawing in the workshop of Suvée when a boy, until 1801. In the early 1810s, he worked as a theatre drawer in the Opéra under the supervision of Degotti and wrote papers for journals and short comedies. He served from 1813 in the French National Guard and was promoted as a captain in the staff of Marshall Comte d'Orsay. Alphonse de Cailleux had become a friend of Taylor in the workshop of Suvée. Trained later as an architect, he entered the French Army in 1815, thanks to Taylor. Cailleux had a strong interest in medieval archaeology.

Just like Nodier, Taylor was a royalist. Both of them cooperated in the preparation of the coronation ceremony of King Charles X in Reims in 1824. Both of them were rewarded: Taylor received the title of baron. Nodier became librarian of the Arsenal Library, the Royal Library at that time. He had there a large apartment. The group of young romantic and royalist artists and writers, 
then known as the "Cénacle" met every week in his salon. Most of the promising men of the coming generation were members of this club: Victor Hugo, Alphonse de Lamartine, Alfred de Vigny and Alexandre Dumas. In 1828, Victor Hugo was asked by the publisher Gosselin to write a novel on Notre Dame de Paris in the style of Walter Scott: a kind of manifesto of the Romantic Movement. Nodier was, in this way, closely associated with the rise of the new artistic and literary preferences of the French intellectual elite of the time - and contributed to shape them.

\section{The Project}

In 1818, the three friends Nodier, Taylor and de Cailleux travelled in Normandy. It was then the part of France where medieval archaeology was the most developed. A former émigré during the Revolution and a local scholar, Charles Duhérissier de Gerville was making an inventory of the churches of the department of Cotentin. Botanist and geologist by taste, he used the taxonomic methods of natural sciences (he was in correspondence with the well-known natural scientist and evolutionist Lamarck) in order to classify these churches. He opposed those with coat hanger vaults to those with pointed arches and proposed to use the qualitative gothic only for the second ones. He knew, thanks to his English correspondents, that Thomas Rickmen, who had made the same distinction for the medieval English churches, used the term 'Norman' for the first group. De Gerville found that it was too restrictive a category since churches of this type were present in many places of France and elsewhere. He thus proposed to speak of architecture romane, as opposed to architecture gothique. The English antiquarian William Gunn accepted his idea and coined the English expression Romanesque architecture. Thanks to this Anglo-French cooperation, Normandy was ahead in the field of medieval archaeology. There were other good specialists of this field in this part of France, as Arcisse de Caumont. Both de Gréville and de Caumont founded the Societé des Antiquaires de Normandie in 1824, using the English term antiquarian rather than the French archaeologist one.

The three friends got enthusiastic with their visit. Since 1811, Taylor dreamed of publishing a book on the Christian archaeology of Europe. He gave the idea to his fellow travellers: they got enthusiastic with it and formed immediately the project to write an archaeological guide of this province.

\section{Taylor as an Entrepreneur and a Communicator}

Taylor structured the project, a very ambitious one: his wish was to put a "portable museum in the hands of those who ignored until then the artistic treasures of France". He found a publisher (Gide) and organized the work. The aim of the book was enlarged: the 24 volumes of Voyages pittoresques et 
romantiques dans l'ancienne France were published from 1820 to $1878^{6}$ (Taylor et al. 1820-1878). It was through this publication that intellectual France people discovered its medieval and Renaissance heritage.

Exploring the French past was a gigantic venture: it meant drawing thousands of ancient monuments and presenting them in an imaginative prose that stressed the atmosphere of the time they were built. The illustration was essential for such a publication. It relied on the quality of drawings and on the new technology of lithography. The collaborators had to travel for years the length and breadth of the provinces they covered.

The three friends were complementary. Charles Nodier, with his strong inclination towards legends and the Middle Ages, gave the publication its romantic atmosphere. As an archaeologist and an architect, Alphonse de Cailleux answered for the scientific quality of the publication. The role of baron Taylor was more important, since he mastered perfectly the new techniques of communication and publicity of the time and headed the venture for sixty years.

Taylor was fully aware of the possibilities offered by lithography, a technique invented in Bavaria by Aloys Senenfeld in 1796. Between the initial discovery (the possibility to use a calcareous stone attacked by an acid in printing activities) and its industrial use, thirty years of further innovations were needed. Louis-François Lejeune diffused the new technique in France. This young painter was transformed into a soldier by the Revolution. He was a general in Napoléon's army when he discovered lithography in Munich in 1806. Charles Philibert de Lasteyrie created the first French lithographic printing house in 1815. A nephew of Senenfeld settled in Paris in 1818. But the most important agent in this diffusion process was Godefroy Engelmann (1788-1839). Born in Mulhouse, trained as a drawer, he entered the manufacture of printed calicos of Thierry in this city in 1808, visited Senenfeld in Munich in 1813-1814 in order to master the new technique, launched a firm specialized in the printing of calicos in Mulhouse in 1814 and moved to Paris where he opened a lithographic printing house in 1816 . He was responsible for most of the innovations, which allowed for the industrialization of lithography. By the end of the 1810s, his printing house was the best in Paris.

Taylor was aware of the possibilities offered by the new technique. Engelmann printed Les Voyages picturesque. In order to achieve a good result, the lithogravers had to rely on very accurate drawings and to use special rules, as defined by Engelmann in his Manuel du dessinateur lithographe (1822). Taylor had to choose first class drawers: well-known painters as Géricault, Isabey, Vernet, Bonington were commissioned in this way. He relied mainly on a few professional drawers, Adrien Dauzats (1804-1868) for instance, with whom he travelled in the Middle East and was a personal friend. Viollet-le-Duc cooperated for the volume on Picardy. As lithographers, Godefroy Engelmann and his stepbrothers, the brothers Thierry, played a central role.

\footnotetext{
${ }^{6}$ The following provinces were covered: Normandy, Franche-Comté, Auvergne, Picardy, Brittany, Languedoc, Dauphiné, Burgundy, Champagne. Northern France, Lorraine, Alsace, Provence, Poitou, Limousin, Aquitaine, and the Loire valley were lacking.
} 
As a "portable museum", les Voyages pittoresques... had to present French monuments in a dramatic way (Figure 1). It was really a field in which Taylor was excellent. He had worked for some years in the Opera as a drawer of decors in the workshop of Degotti. He had met there Louis Daguerre (17871851), who had a strong interest in the problems of perspective and light in presenting a play. With another painter, Charles-Marie Bouton, Daguerre imagined what they call the Diorama: a way to stage plays dramatically. It relied on the painting of huge canvases, which could be lightly in different ways: with front lights, as a painting, or with backlights, by transparency. Changing the lights transformed the scenery and provided it with some dynamism - prefiguring, in this way pictures. The interest of Daguerre in the rendering of scenes led it later, from 1829, to cooperate with the inventor of photography, Nicéphore Niepce, and to develop the first form of commercial photography with the daguerreotype (1839).

Figure 1. The Romantic Atmosphere of French Landscapes and Monuments: the Cité of Carcassonne

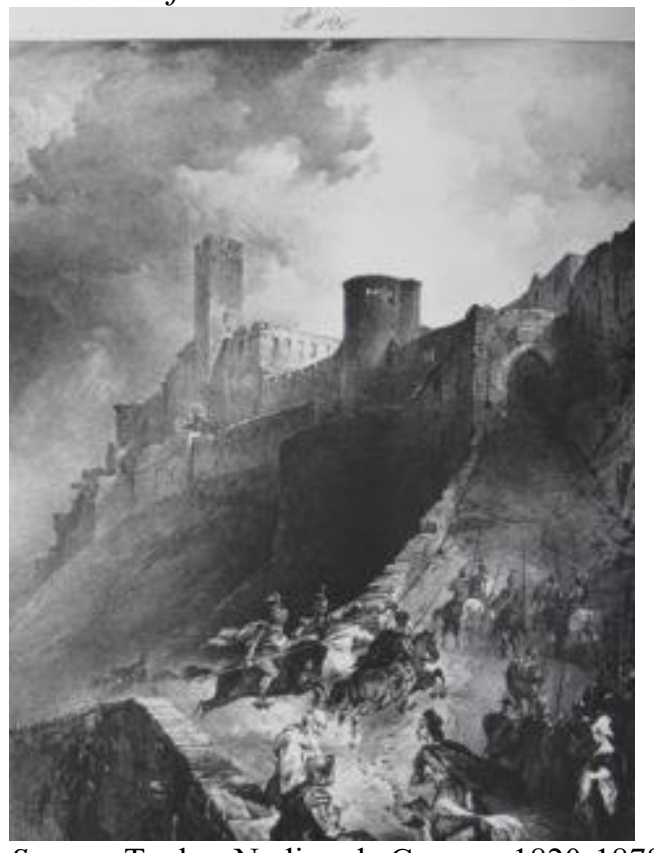

Source: Taylor, Nodier, de Cayeux, 1820-1878.

Diaroma was used to present melodramas. It was very successful. Taylor participated in the venture. He wrote a melodrama for it. In his way to organize the Voyages pittoresques he chose to surround, or encapsulate, texts in complex decors, just like the stage of a play. Viollet-le-Duc was especially successful in this kind of presentation (Figure 2).

The lithographs themselves were rendered more dramatic by the way they were lighted: the effect was especially spectacular for some castles or churches.

Managing such a project as Les Voyages pittoresques... was also a gigantic financial responsibility. Gide was the publisher and acted also as a banker. The printer was Firmin Didot. In order to limit the advances of capital, Taylor and 
Gide chose a form of publication, which was then widely used: the publication by parts, which had to be later, gathered and bound into volumes. As a result, the first part of Les Voyages pittoresques... was issued in 1820, only two years after launching the project.

Figure 2. The Art of Transforming a Page into a Show: Viollet-le-Duc's Frontispiece Presenting the Surroundings of Amiens, in Picardy

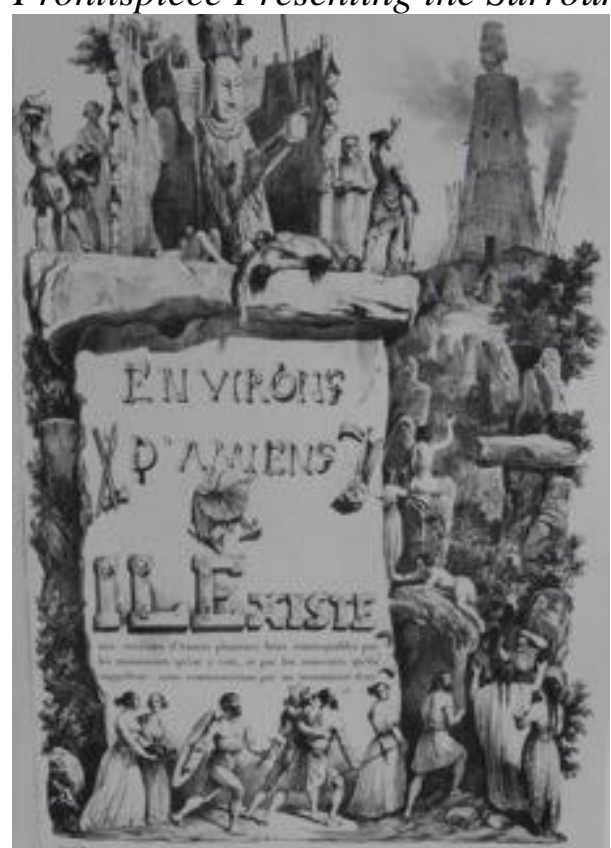

Source: Taylor, Nodier, de Cayeux, 1820-1878.

\section{Communicating about Cultural Heritage in the $19^{\text {th }}$ century}

Communicating about cultural heritage in the $19^{\text {th }}$ century was a difficult task: the idea of cultural heritage was a new one - or at least, it became to be formulated in a completely different way: it ceased to be rooted in religious faith and religious history. It became to be rooted in cultural - and more specifically monumental heritage., Taylor, Nodier and de Cailleux were among the first intellectuals to develop an interest in that field: they chose up to gather information on it - and a form of graphic information for building a "portable museum", an efficient way to diffuse the new sensibility.

Nodier was more focused on the new romantic imaginary and its literary expression. As a professional librarian, the imperative of conservation was quite clear for him. De Cailleux had the archaeological training which was needed in order to animate and control at the same time the gathering of the graphic information the new movement needed. He had also a strong interest in heritage preservation. He soon became in curator of the museums: at the end of his career, he was the director of the Louvre Museum in Paris.

Baron Taylor was different: he had been trained as a drawer, but he was more attracted by the show business - and was one of the first entrepreneurs in that field. He participated in the development of the new forms it was taking at 
that time: he wrote melodrama, had them played in the diorama - the most imaginative stage yet conceived. He conceived editing information relative to monumental heritage in the same way and presented it as a graphic show, for which he mobilized the most efficient techniques of the time: lithography. From the 1820s and for more than thirty years, he was Royal Commissioner of the Théâtre français.

His career was a complex one. He liked travelling - a way for him to discover the kind of cultural heritage he liked. He toured in this way France, Britain, Scotland, the Netherlands and Italy - a kind of Grand Tour centred on France, and not on Britain. But for many of his travels, he received a commission from the French Ministry of Foreign Affairs: he was known for his diplomatic quality and his discretion. He was sent in this way to Egypt in order to organize the transport of the obelisk of Louqsor that Mehemet Ali had offered to France. Later, he travelled in Spain in order to buy the paintings of the great Spanish artists of the $16^{\text {th }}, 17^{\text {th }}$ and $18^{\text {th }}$ centuries that were then available as a consequence of the nationalization of Church properties by the Spanish government: he was in this way responsible for the development of the Spanish section of the Louvre Museum. In Egypt as well as in Spain, he launched a local version of his Voyages pittoresques...

His action was not limited to the inventory of monumental heritage, the diffusion of graphic information on it, and its preservation. He had understood that literature and show business were essential for a modern society: because he was naturally very generous, he struggled for the defence of artists and authors. He founded a charitable organization to help artists and authors and helped the Société des Gens de Lettres in the perception of copyrights.

A well-educated and handsome man, Baron Taylor developed long-term relations with persons working in many fields. He was excellent in communicating on cultural heritage as well as in organizing new forms of popular shows, the Diorama (1822-1839) for instance. Baron Taylor has high diplomatic qualities and was a fantastic businessman. As a result, the Voyages pittoresques... were a very successful venture in building and diffusing the image of a cultural heritage.

\section{Conclusion}

In the Greek as well in the French cases, the rising expectations of new audiences concerning cultural heritage as a source of identity were essential in the decision to collect and diffuse information. In both cases, the work required an extensive collection of information. Pausanias had a political aim: claiming, in front of Rome, the grandeur of Greece as proved by the remains of its bright past. In the French case, the development of new means for diffusing graphic information was essential.

The nature of cultural heritage was not the same in Antique Greece and $19^{\text {th }}$ Century France: it was largely religious in the case of Greece - and the statues were important since they were, in a sense, really the gods; it was 
mainly based on artistic and monumental remains of the past in the case of France.

Collecting data for such ventures needed a tremendous work: Pausanias spent thirty years of his life travelling all over Greece in order to cover the whole country and write its presentation. He could only rely on the text he wrote to convey his experience. Baron Taylor organized, and maintained for sixty years, a team of drawers and painters in order to visit the French provinces and draw thousands of monuments or landscapes. He took full advantage of the new technique of lithography to create a romantic atmosphere in the 24 volumes he produced. In order to finance this gigantic venture, he relied on the publication of the successive volumes in parts, which were later bound together. The whole work relied on all the new techniques of communication then available. He was a great pioneer in the field of cultural communication in the $19^{\text {th }}$ century.

\section{References}

\section{Sources: The Text of Pausanias}

Teubner ed.: M H Rocha-Pereira (1989-1990) Pausaniae Graeciae Descriptio, 3 vol., Loeb ed.: WHS Jones (1960-1964) Description of Greece. London, Loeb Classical Library, 5 vol.

Papachetzes N (1974- 1981) Pausaniou Hellados Periegesis, Athens.

Collection of the French Universities, Pausanias, description de la Grèce [Description of the Greece of Pausanias] texte établi par M. Casevitz et traduit par J. Pouilloux (I, 1992; V, 1999; VI, 2002), J Auberger (IV, 2005), Y Lafond (VII, 2000) and M. Jost (VIII, 1998).

Italian ed.: Pausanias. Guida della Grecia [Pausanias. Guide of Greece] integrates the recent results of archaeological research (many maps) and is characterized by a very rich reflexion. D Musti (I, 1987), D Musti and Torelli (II, 1994; III, 1991; IV, 1994), G Maddoli and V Saladino (V, 1998); G Maddoli and M Nafissi (VI, 1999), M Noggi (VII, 2000 and VIII, 2003), M Moggi and M Osanna (IX, 2010)

\section{Short Bibliography}

Bingen J (ed) (1996) Pausanias historien. Entretiens sur l'Antiquité classique [Pausanias historian. Discussions on Classical Antiquity]. Vandœuvre/Genève.

Ellinger P (2005) La fin des maux: d'un Pausanias à l'autre: essai de mythologie et d'histoire [The End of Evils. From a Pausanias to Another One: an Essay on Mythology and History]. Paris.

Elsner Ch (1992) Pausanias, a Greek Pilgrim in the Roman World. Past and Present 135: 3-29.

Habicht Ch (1985/1998) Pausanias'guide to Ancient Greec. Berkeley.

Jacob Ch (1980) Paysages hantés et jardins merveilleux de la Grèce imaginaire de Pausanias [Haunted landscapes and marvellous gardens in the imaginary Greece of Pausanias]. L'Ethnographie I: 35-67.

Jacquemin A (1996) Les curiosités naturelles chez Pausanias [The Natural Curiosities in Pausanias]. In G Siebert (ed) Nature et paysage dans la pensée et 
l'environnement des civilisations antiques, Actes du colloque de Strasbourg (1992), 121-128. Paris.

Jost M (2006) Unité et diversité. La Grèce de Pausanias [Unity and Diversity. The Greece of Pausanias]. REG $119:$ 568-587.

Jourdain-Annequin C (1998) Représenter les dieux: Pausanias et le panthéon des cités [Representing Gods: Pausanias and the Pantheon of Cities]. Kernos, suppl. 8, 241-261.

Jourdain-Annequin, C (2014) Pausanias, un marcheur en Grèce ancienne [Pasanias, a Walker in Ancient Greece]. Natures, miroirs des hommes, 237-248. Paris, L'Harmattan, Coll. Géographie et cultures.

Jourdain-Annequin C (2017) Du murmure cristallin des sources à l'eau du Styx: le role de l'eau dans la Grèce de Pausanias [From the Crystalline Murmur of Springs to the Water of Styx: the Role of Water in the Greece of Pausanias]. In P Bonnechère, M C Beaulieu (eds) Water in Greek Religion, Tufts' Conference (2014).

Noeppler DK, Piérart M (eds) (2001) Editer, traduire, commenter Pausanias en l'an 2000 [Editing, Translatind, Commenting Pausanias in the Year 2000]. NeuchâtelGenève.

Pirenne-Delforge V (2008) Retour à la source. Pausanias et la religion grecque (with an important bibliography) [Coming back to the source. Pausanias and the Greek Religion].

Pirenne-Delforge V, Purnelle G (1997) Pausanias. Periegesis. Index verborum. Index de fréquence. Index nominum [Pausanias. Periegesis. Index of Verbs, Index of Frequency, Index of Words]. Liège.

Taylor I, Nodier C, de Cayeux A (1820-1878) Les Voyages pittoresques et romantiques dans l'ancienne France. Paris, Gide, 24 vol. 
